\title{
What We Know About Stemflow's Infiltration Area
}

\author{
John T. Van Stan $I^{1,2 \star}$ and Scott T. Allen ${ }^{3}$ \\ ${ }^{1}$ Applied Coastal Research Laboratory, Georgia Southern University, Savannah, GA, United States, ${ }^{2}$ Department of Geology \\ and Geography, Georgia Southern University, Statesboro, GA, United States, ${ }^{3}$ Department of Geology and Geophysics, \\ University of Utah, Salt Lake City, UT, United States
}

\section{OPEN ACCESS}

Edited by:

Charles Rhett Jackson,

University of Georgia, Georgia

Reviewed by:

Courtney M. Siegert,

Mississippi State University,

United States

Seyed Mohammad Moein Sadeghi,

University of Tehran, Iran

*Correspondence:

John T. Van Stan II

jvanstan@georgiasouthern.edu

Specialty section:

This article was submitted to

Forest Hydrology,

a section of the journal

Frontiers in Forests and Global

Change

Received: 05 February 2020

Accepted: 28 April 2020

Published: 27 May 2020

Citation:

Van Stan JT II and Allen ST (2020)

What We Know About Stemflow's Infiltration Area

Front. For. Glob. Change 3:61. doi: 10.3389/ffgc.2020.00061
A portion of precipitation drains to the surface down plant stems, as "stemflow." Although per observations to date, stemflow rarely represents $>2 \%$ of gross precipitation in forests, it can result in larger water fluxes to near-stem soils that are hypothetically more important to roots. The ecohydrological importance of stemflow is often predicated upon assumptions about how it infiltrates into near-stem soils. Our objective is to review the small number of studies over the $\sim 140$ years of stemflow research that have quantified its infiltration area (i.e., soil surface area over which stemflow spreads while infiltrating). We found several empirical descriptions of stemflow infiltration areas inferred from disparate approaches, and we discuss that evidence in the context of dominant assumptions and conceptualizations (i.e., equating infiltration area to basal area or estimations based on assumed soil conductivity metrics). However, we conclude that a more empirical understanding of stemflow infiltration is needed before we quantify or qualify stemflow's influence from its assumed infiltration rate. Toward this goal, we provide a critical discussion of two methods (stable isotopes and dye tracing) that seem most promising for quantifying stemflow infiltration area.

\section{Keywords: stemflow, infiltration, funneling ratio, forest, precipitation partitioning}

\section{INTRODUCTION}

Precipitation is redistributed by forest canopies into spatiotemporally heterogeneous patterns at the forest floor. This redistribution, however, is not always random and can involve the routing of water to specific places: notably, large canopy areas can capture and drain precipitation to the tree stem and down to nearby soils as stemflow (Tanaka et al., 1996; Metzger et al., 2019). This stemflow generation is highly variable across forest species and storm characteristics, but rarely exceeds $2 \%$ of the precipitation inputs to a forest (Carlyle-Moses et al., 2018; Van Stan and Gordon, 2018). Nonetheless, for over a century, researchers have argued that these small amounts of stemflow can be remarkably important if canopies funnel water such that it preferentially infiltrates around the stem base (Riegler, 1881; Pressland, 1973; Carlyle-Moses et al., 2018). This process is often quantified per "funneling ratios" ( $F$; Herwitz, 1986):

$$
F=\frac{S_{T}}{P \cdot I_{T}}
$$

where $S_{T}$ is stemflow volume ( $\mathrm{L}$ tree $\left.{ }^{-1}\right), P$ is depth $(\mathrm{mm})$ of gross rainfall or throughfall to be compared with $S_{T}$, and $I_{T}$ is infiltration area $\left(\mathrm{m}^{2}\right.$ tree $\left.{ }^{-1}\right)$, often assumed equal to stem basal area $\left(\mathrm{m}^{2}\right)$ (Figure 1a: Herwitz, 1986). For $F>1$, stem cross sectional areas receive more precipitation due to contributions of the tree crown than equivalent areas of open ground. However, the area of 


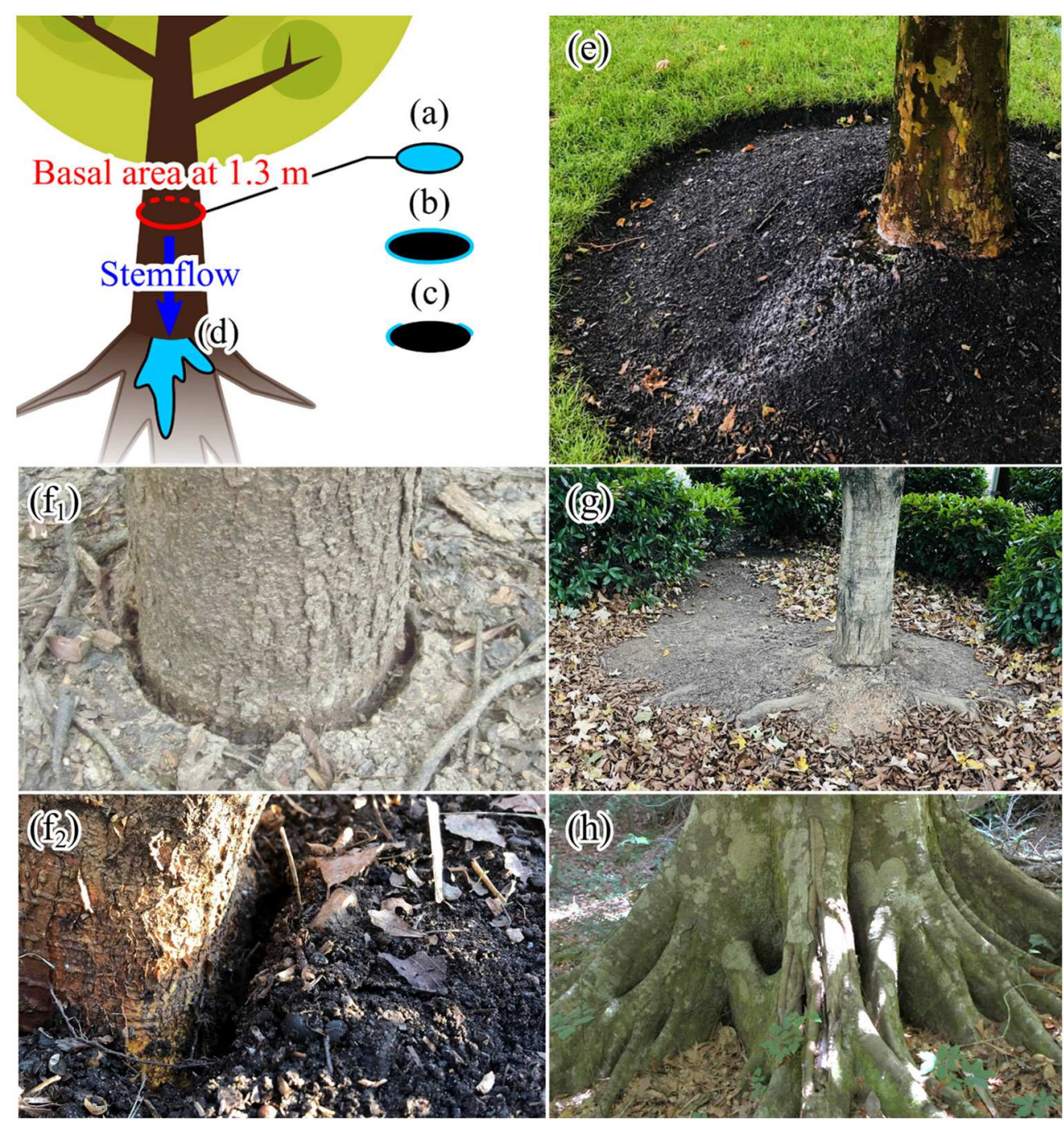

FIGURE 1 | Conceptualizations of stemflow infiltration area $\left(I_{T}\right)$, (a) represented as a function of stem basal area (Herwitz, 1986), (b) assumed equal to the minimum area around the stem that could transmit stemflow inputs (Gómez et al., 2002), (c) inferred from localized stemflow pathways given assumed saturated conductivity rates (Imamura et al., 2017; Carlyle-Moses et al., 2018), (d) inferred empirically from photographed, video-recorded, and scour-based observations (this study, from

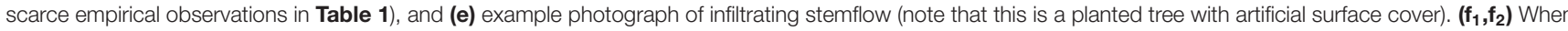
a gap is present between the stem base and soils, it is reasonable to think that substantial stemflow infiltration may occur immediately beside the stem. Alternatively, (g) litter scour marks suggest large stemflow infiltration areas or (h) wide root bases may provide physical impediments to infiltration and, thus, we would expect infiltration areas to be larger (photos by authors).

soil that water actually infiltrates into is unlikely to equal stem basal area. This is because stemflow water presumably infiltrates both vertically and laterally around the stem perimeter (Figure 1b; Gómez et al., 2002); perhaps at discrete locations receiving distinct stemflow rivulets (Figure 1c; Imamura et al., 2017). As early as the mid-twentieth century, (Voigt, 1960) simulated stemflow and observed soilwater responses that led him to conclude that stemflow infiltrated within $0.3 \mathrm{~m}$ of the stem base (i.e., $I_{T}$ values that are substantially larger than the trees' basal areas).

Although Herwitz's (1986) equation for $F$ employs the concept of $I_{T}$, it was not intended to be a literal representation of how stemflow infiltrates, and recent work acknowledges that the $F$ metric requires a more realistic $I_{T}$ parameter (Carlyle-Moses et al., 2018). A more realistic $I_{T}$ parameter is needed to more precisely understand the effects of stemflow on individual trees (which requires considering where that stemflow infiltrates and to where it flows, e.g., to roots, into the soil matrix, or through macropores). A benefit of continuing to use the basal-area $F$ is that values exist for a wide variety of shrub and tree species around the globe which can permit size-standardized cross-site comparisons (Levia and Germer, 2015; Van Stan and Gordon, 2018). Another benefit is that, when predicting stemflow volumes where stemflow is not measured, species- and size-specific $F$ 
values measured elsewhere could be used to predict stemflow yields in stands where only basal areas and precipitation inputs are known.

Published observations that explicitly describe the size of $I_{T}$ are scarce; however, there are pieces of evidence that suggest $I_{T}$ is larger, $10^{-1}-10^{1} \mathrm{~m}^{2}$ (Voigt, 1960; Pressland, 1973, 1976; Herwitz, 1986; Tanaka et al., 1991; Gómez et al., 2002; Iida et al., 2005; Chinen, 2007; Charlier et al., 2009; Keen et al., 2010; Schwärzel et al., 2012; Rashid and Askari, 2014; Gonzalez-Ollauri et al., 2020), than the areas assumed elsewhere, e.g., $10^{-4}-10^{-1}$ $\mathrm{m}^{2}$ (Iida et al., 2016; McKee and Carlyle-Moses, 2017; CarlyleMoses et al., 2018). Studies have described stemflow infiltration pathways that include large "fingers" spreading outward from stems (Figures 1d,e; Chinen, 2007; Rashid and Askari, 2014), or large areas of runoff (Charlier et al., 2009; Keen et al., 2010). Here we review those previous observations and discuss how they may conflict with assumed infiltration areas, demonstrating the potential for inferential errors regarding how stemflow moves through the critical zone [i.e., as localized intense infiltration that percolates deeply at stems (Carlyle-Moses et al., 2018), as diffuse infiltration around stems (Voigt, 1960), or as surface runoff (Keen et al., 2010)]. To be clear, we recognize that stemflow fluxes can be larger at the surface than open rainfall or mean throughfall for certain ecosystems, and we do not disregard stemflow's potential ecological relevance. However, given that claims about stemflow's ecohydrological relevance are often predicated upon assumptions about its (small) infiltration area (Riegler, 1881; Carlyle-Moses et al., 2018), we believe it is important to critically review the scarce measurements that are useful in constraining such assumptions.

\section{ESTIMATING STEMFLOW INFILTRATION AREAS $\left(I_{T}\right)$}

Estimates of $I_{T}$ have been made from various types of observations: post-storm litter marks caused by infiltration excess (Tanaka et al., 1991; Iida et al., 2005; Rashid and Askari, 2014); post-storm soil scour marks originating at the stem (Tanaka et al., 1991; Chinen, 2007); video recordings during storms (Cattan et al., 2009; Charlier et al., 2009; Keen et al., 2010); simulated stemflow during dry periods (Voigt, 1960; Schwärzel et al., 2012); in-storm measurement of the infiltration ring itself (Pressland, 1973, 1976; Gómez et al., 2002); dye tests (Spencer and van Meerveld, 2016; Imamura et al., 2017; Carlyle-Moses et al., 2018; Gonzalez-Ollauri et al., 2020); and estimates based on site-specific stemflow and near-stem infiltration rates (de Ploey, 1982; Herwitz, 1986; Gómez et al., 2002; Carlyle-Moses et al., 2018). Marks due to litter relocation and soil scour are difficult to interpret quantitatively, because these areas do not represent mean $I_{T}$ for an individual storm, nor do they represent the maximum $I_{T}$ for any given storm (although these $I_{T}$ estimates are typically the largest areas reported: Table 1). They likely underestimate maximum $I_{T}$ per storm, because they only represent the area where stemflow runoff mobilized the greatest leaf biomass or had flow velocities great enough to incise channels into the sediments. Stemflow simulations have rarely been done (Schwärzel et al., 2012; Spencer and van Meerveld, 2016; Gonzalez-Ollauri et al., 2020; Guo et al., 2020), and only one of these studies explicitly reported an $I_{T}$ observation (Schwärzel et al., 2012)—which likely represents a minimum $I_{T}$ (see footnotes in Table 1). Altogether, we found 11 infiltration areas reported or able to be estimated based on available data, and an additional 2 studies which reported runoff (Table 1).

Others have computed expected infiltration areas. $I_{T}$ in forests has been estimated through dividing mean stemflow rate per tree, $S_{r}\left(\mathrm{~L}\right.$ tree $\left.{ }^{-1} \mathrm{~h}^{-1}\right)$ by the saturated hydraulic conductivity of the soil surface, $K_{\text {sat }}\left(\mathrm{mm} \mathrm{h}^{-1}\right)$ :

$$
I_{T}=\frac{S_{r}}{K_{s a t}} .
$$

This equation (modified from Carlyle-Moses et al., 2018), assumes that so long as inferred $K_{\text {sat }}>S_{r}$, stemflow will immediately infiltrate. At the stand scale, where stems often occupy $0.1-1 \%$ of forests (Hall, 2003), and with a recommended range of inferred $K_{\text {sat }}=100$ to $>1,000 \mathrm{~mm} \mathrm{~h}^{-1}$ (Carlyle-Moses et al., 2018), this assumption yields stemflow infiltration area estimates that are a much smaller fraction of ground area $\left(10^{-4}\right.$ $10^{0} \%$ of plot area; Carlyle-Moses et al., 2018). Carlyle-Moses et al. (2018) showed that this can lead to $I_{T}$ values that are smaller than that of basal areas (i.e., $<1 \%$ of basal area $\mathrm{ha}^{-1}$ ); thus, the resulting $F$ can be orders of magnitude higher than those reported using basal area as the assumed infiltration area. For example, stand-scale $F$ in a lowland tropical forest site increases from 4.6 (per basal area) to 151.8 (per eq. 2), suggesting that the $<1 \%$ of rainfall that becomes stemflow results in a "mean depth of stemflow infiltration $>15,000 \%$ of the (open) precipitation" (Carlyle-Moses et al., 2018)! While this conceptualization of stemflow as a ring (or partial ring) around stems is physically more accurate than representations of $I_{T}$ on basal area (Figure 1), the inferred intensity of stemflow inputs into soils around stems would be exaggerated if $I_{T}$ is systematically underestimated by Equation (2). On the other hand, given the sometimes-observable gap between stems and soils (Figures $\mathbf{1 f}_{\mathbf{1}}, \mathbf{f}_{\mathbf{2}}$ ), we speculate that infiltration areas may sometimes be much smaller than would be predicted as a function of soil conductivity if these gaps extend deeper into the subsurface to facilitate flow along coarse roots (e.g., Schwärzel et al., 2012; Spencer and van Meerveld, 2016). Ultimately, existing stemflow infiltration data do not yet support generalizations about $I_{T}$.

From all estimation methods the reported range of $I_{T}$ is $0.04-$ $11.83 \mathrm{~m}^{2}$ tree ${ }^{-1}$, across various storm conditions and trees with diameters of 6-97 cm (Table 1). Some sites in (Table 1) did not report an $I_{T}$ value as they directly observed runoff (Charlier et al., 2009; Keen et al., 2010). Spencer and van Meerveld (2016) did not report an $I_{T}$, but described finding dyed stemflow as much as $40 \mathrm{~cm}$ away from the stem (in the top $10 \mathrm{~cm}$ of soil). The complex patterns of the infiltration reported by Spencer and van Meerveld (2016) did not permit $I_{T}$ estimation (but see mapped dye cross sections provided in the figures and supplement). GonzalezOllauri et al. (2020) also did not report an $I_{T}$, but photographs of the soils after the dye tests, in Figure 1b of Gonzalez-Ollauri et al. (2020), show ellipse-shaped stained surface soils downslope 
TABLE 1 | Stemflow infiltration areas $\left(I_{T}\right)$ reported from previous work.

\begin{tabular}{|c|c|c|c|c|c|c|c|}
\hline \multirow[t]{2}{*}{ Study } & \multirow[t]{2}{*}{ Setting } & \multicolumn{2}{|c|}{$I_{T}$} & \multicolumn{3}{|c|}{ Storm conditions } & \multirow{2}{*}{$\begin{array}{c}\text { Tree size } \\
\text { Range (cm } \\
\text { DBH) }\end{array}$} \\
\hline & & $\begin{array}{c}\operatorname{Min}\left(\mathrm{m}^{2}\right. \\
\left.\operatorname{tree}^{-1}\right)\end{array}$ & $\begin{array}{c}\operatorname{Max}\left(m^{2}\right. \\
\left.\operatorname{tree}^{-1}\right)\end{array}$ & $\begin{array}{c}\text { Amount } \\
(\mathrm{mm})\end{array}$ & $\begin{array}{l}\text { Intensity } \\
\left(\mathrm{mm} \mathrm{h}^{-1}\right)\end{array}$ & $n$ (storms) & \\
\hline \multirow[t]{2}{*}{ Carlyle-Moses et al. (2018) } & Juvenile pine plantation & 0.0018 & 0.031 & $5.9-16.0$ & - & 3 & $2-5$ \\
\hline & Lowland tropical forest & 0.0016 & - & - & - & 130 & $19-36^{\star}$ \\
\hline Charlier et al. (2009) & Banana plantation & \multicolumn{2}{|c|}{ Significant surface runoff } & - & $1.0-61.0$ & 40 & $10-15$ \\
\hline Chinen (2007) & Reforested agricultural field & 1.12 & 4.75 & 20.7 & $\sim 60.0$ & 1 & $17-40$ \\
\hline Gómez et al. (2002) & Olive orchard & 0.04 & 1.12 & $0.6-77.1$ & - & 12 & 26 \\
\hline Gonzalez-Ollauri et al. (2020) & Suburban forest fragment & $-^{\ddagger}$ & $1.25-5.07^{\ddagger}$ & $9.8-39.6^{\dagger}$ & $16.8-67.8^{\dagger}$ & $1^{\dagger}$ & $37-49$ \\
\hline Herwitz (1986) & Montane tropical forest & 0.13 & 3.09 & $11.8-51.6$ & $73.7-118.0$ & 2 & $30-48$ \\
\hline lida et al. (2005) & Urban (campus) forest & 0.4 & 1.28 & $18.0-88.5$ & $1.1-2.3$ & 2 & $31-63$ \\
\hline Keen et al. (2010) & Macadamia orchard & \multicolumn{2}{|c|}{ Significant surface runoff } & $10.0-217.0$ & - & $-^{\wedge}$ & - \\
\hline Pressland $(1973,1976)$ & Acacia (mulga) forest & 0.34 & 1.37 & $0.3-120.0$ & - & 46 & $6-38$ \\
\hline Rashid and Askari (2014) & Oil palm plantation & 6.8 & 11.83 & - & - & - & $58-97$ \\
\hline Schwärzel et al. (2012) & Temperate beech forest & $0.25^{x}$ & - & 18 & $-x$ & 1 & 32 \\
\hline Tanaka et al. (1991) & Urban (campus) forest & 0.04 & 0.23 & $\sim 2$ & - & 1 & $9-43$ \\
\hline Voigt (1960) & Temperate deciduous forest & - & $0.44-0.52^{\#}$ & $-\#$ & $-\#$ & $-^{\#}$ & $15-24$ \\
\hline
\end{tabular}

Some studies did not explicitly report IT due to observed significant runoff induced by stemflow (see text for description).

${ }^{\star}$ Reported in Table 2 of lida et al. (2016).

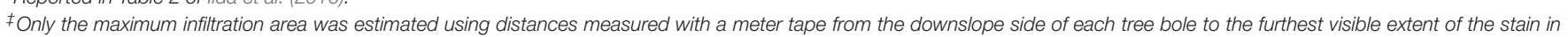
the downslope direction (127 cm for study tree \#1 and $63 \mathrm{~cm}$ for study tree \#2 per with the study's corresponding author).

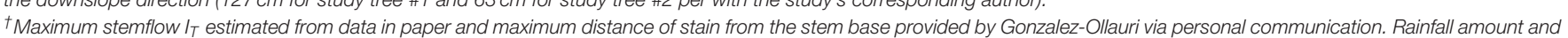

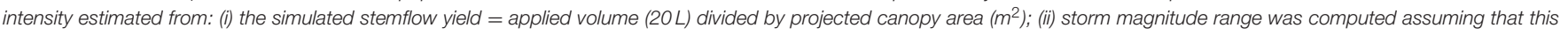

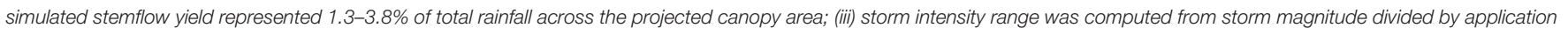
time (35 min).

$\wedge$ Number of storms was not reported by Keen et al. (2010), but their study spanned 18 months of rainfall.

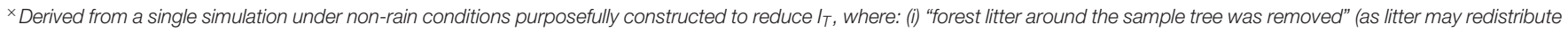

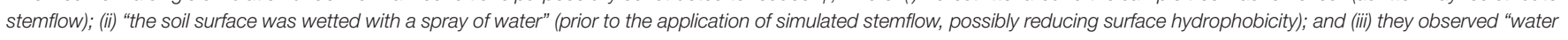
entry into the soil, and if necessary (when water spread over the soil surface), reduce(d) the irrigation rate (or, simulated stemflow rate)".

\#Estimates were of a 0.3048-m radius around stems based on soilwater sensor responses during simulated stemflow. See also the collar experiments described in Voigt (1960).

(likely due to surface runoff) under natural simulated stemflow rates. If the Gonzalez-Ollauri et al. (2020) basal-area $F$ values $(0.1$ to $>9.0)$ are divided by the observed $I_{T}$ in (Table 1$)$, the revised range of $F$ decreases to $0.0-1$.6. It has been claimed that $I_{T}$ "values in the range of 1 to $2 \mathrm{~m}^{2}$ (tree ${ }^{-1}$ ) are almost always associated with extreme precipitation conditions," specifically, intense rainfall rates (Carlyle-Moses et al., 2018). However, $I_{T}$ $>1 \mathrm{~m}^{2}$ tree ${ }^{-1}$ has been reported under low rainfall intensities, 1-2 $\mathrm{mm} \mathrm{h}^{-1}$ (Iida et al., 2005), and for a small storm, $\sim 2.0 \mathrm{~mm}$ (Tanaka et al., 1991 in Iida et al., 2005). In fact, Iida et al. (2005) provide photographs of litter marks showing $I_{T}=0.4-1.3$ $\mathrm{m}^{2}$ tree ${ }^{-1}$ under non-extreme precipitation conditions (again, note that litter marks may not represent the maximum $I_{T}$ ). It is important to note that existing $I_{T}$ estimates are mostly from agricultural, urban or managed plantation settings, leaving $I_{T}$ in natural forests under-researched.

\section{CHALLENGES IN ESTIMATING STEMFLOW INFILTRATION AREA $\left(I_{T}\right)$}

To integrate stemflow processes into broader hydrological and ecological models and conceptual frameworks, $I_{T}$ estimates need to be further constrained by empirical data. Misrepresentations of $I_{T}$ could result in errors in estimating the role of stemflow in surface runoff and erosion (Cattan et al., 2009; Charlier et al., 2009; Keen et al., 2010) and deep recharge via concentrated infiltration into a small area (Voigt, 1960). Even a seemingly straightforward assumption, that stemflow will infiltrate so long as $S_{r}$ is less than an inferred $K_{s a t}$, can underestimate $I_{T}$ to a degree such that it results in significant differences in the resulting/expected hydrological process. For example, significant surface erosion can be attributed to stemflow intensities exceeding infiltration capacities and flowing laterally. Keen et al. (2010) estimated substantial stemflow-related runoff and erosion carried away $3.8 \mathrm{t} \mathrm{ha}^{-2} \mathrm{y}^{-1}$ of soils, a phenomenon that may be overlooked if too-small infiltration areas were assumed.

Regarding $S_{r}$, one must take care to include the input of throughfall $\left(\mathrm{mm} \mathrm{h}^{-1}\right)$ within the area defined by $I_{T}$, which can range from being small, $<10 \%$ (Fathizadeh et al., 2014), to significant augmentations to stemflow rates, $>30 \%$ (Gómez et al., 2002). Stemflow can also "splash" from the bark as it flows to the surface, especially on rough bark, thereby expanding the soil surface area over which stemflow is distributed. For example, Voigt (1960) showed that much of stemflow splashes off of stems, up to $0.5 \mathrm{~m}$ away, dramatically widening the radius of influence and potential stemflow infiltration area. As $I_{T}$ likely varies with rainfall rate, the augmentation of $S_{r}$ by throughfall 
and stemflow splash over these varying areas will also vary with rainfall rate. Since $I_{T}$ is estimated at the sub-plot scale, estimates of additional local throughfall inputs will require knowledge of the large spatiotemporal variability of throughfall (Zimmermann and Zimmermann, 2014). If much of stemflow splashes from stems before reaching the soil surface, then it would also need to percolate through the litter layer, a storage that may intercept, spatially redistribute, and buffer stemflow (Gerrits and Savenije, 2011; Van Stan and Gordon, 2018).

Regarding inferred $K_{s a t}$, there are multiple factors that can result in differences between inferred $K_{\text {sat }}$ and actual infiltrability. Firstly, topsoils are likely unsaturated when stemflow first contacts the surface and, in order to infiltrate, stemflow will need to displace air in the soil pores (Horton, 1933; Linden and Dixon, 1976). The entrapment of air by infiltrating waters is particularly relevant, having been reported to reduce infiltration by $60 \%$ (e.g., Jelinkova et al., 2011); its representation remains challenging (Beven, 2018; Guo and Lin, 2018). Soil hydrophobicity may also reduce infiltrability of stemflow, as its patterns are variable in space and time (Doerr and Ritsema, 2006). Water repellency appears to be present in surface soils of all major textural types at vegetated sites, even when undisturbed (Doerr et al., 2006; de Jonge et al., 2009; Goebel et al., 2011) and can develop during inter-storm dry periods (Ferreira et al., 2016; Gimbel et al., 2016). Even given favorable circumstances at the soil surface, other vertical factors can alter stemflow's capability to infiltrate: for example, $K_{\text {sat }}$ may vary significantly with soil depth and laterally (Herwitz, 1986). Alternatively, structural anomalies (e.g., gaps between soils and stems) could dramatically enhance soils infiltrability and reduce $I_{T}$.

Finally, near-stem belowground volume can be mostly occupied by large roots (Ryan and McGarity, 1983; Clemente et al., 2005), where root:soil cross-sectional area ratio decreases laterally with distance from the stem (Abdi and Deljouei, 2019; Moresi et al., 2019), hypothetically causing much of stemflow entering soils to be physically forced to move laterally. For example, researchers often describe beech (Fagus sylvatica, L. and F. grandifolia, Ehrh.) trees as having very high stemflow rates (Gersper and Holowaychuk, 1971; Falkengren-Grerup, 1989; Germer et al., 2012; Van Stan and Gordon, 2018), due to their smooth bark (e.g., Van Stan et al., 2016), but they also have wide, flared bases with roots extending laterally (Figure 1h) that complicate any assumptions about how those stemflow waters would infiltrate. Thus, the level of disagreement between $I_{T}$ predicted from inferred $K_{\text {sat }}$ and $S_{r}$ and real-world observations might be substantial and problematic. Consistent occurrence of stemflow runoff has also been video recorded in a banana plantation (Cattan et al., 2009) and modeled (Charlier et al., 2009). Indeed, Charlier et al. (2009) opted to use a "stemflow function (that) allowed runoff to be simulated for rainfall intensities lower than the $K_{\text {sat }}$ measured at the soil surface." Similar stemflow-induced erosion has been observed in other settings besides forests, like beneath corn and sorghum under simulated rainfall (Bui and Box, 1992). Importantly, we lack a broad, fundamental understanding of stemflow's subsurface interactions at the very start of infiltration: e.g., what is the shape and size of $I_{T}$ ? How is it controlled by surface cover, topography or root architecture?

\section{HOW TO DETECT STEMFLOW INFILTRATION AREAS}

Problematically, most of our few examples where infiltration areas have been measured are qualitative or anecdotal [see section on "Estimating stemflow infiltration areas $\left(\mathrm{I}_{T}\right)$ "] and mostly not in natural forests (Table 1) and, thus, do not necessarily capture what we would expect to occur in forests. Systematic measurements of infiltration areas are needed to improve our process-level understanding of how stemflow infiltration affects (plant-available) soil-water. Moreover, characterizing those infiltration areas is a first step toward using those infiltration areas in calculations of $F$ (as proposed by CarlyleMoses et al., 2018).

Dye tracers have long been used to trace infiltration processes, but in this case, dye would have to be exclusively applied to stemflow. This has been done through artificially producing stemflow [e.g., using a backpack sprayer (Spencer and van Meerveld, 2016; Gonzalez-Ollauri et al., 2020)]; however, extensive excavation is required to measure dye infiltration patterns, limiting the possibility for replication. Furthermore, dye tends to mostly provide qualitative information on where stemflow is infiltrating; it is not a conservative tracer and cannot be used to quantify how much stemflow reaches any specific area. Dye, however, does provide evidence related to the testing of the "double-funneling" hypothesis (Spencer and van Meerveld, 2016), that stemflow is not only concentrated from the canopy to the stems, but that it is also preferentially funneled to roots (Johnson and Lehmann, 2006).

Stable isotope tracers are another option for discerning where stemflow infiltrates. While isotopic differences between throughfall and stemflow can be large for individual events, those differences are inconsistent in magnitude and sign (Allen et al., 2017); whereas throughfall may be isotopically heavier than stemflow in one event, the opposite may be true of the next event. Considering this type of variability and the long residence times of soil-water (i.e., reflecting many previous events), it is unlikely that stemflow could be reliably discerned from throughfall in soils (e.g., Snelgrove et al., 2020). Alternatively, applying deuterated water as a tracer spike could provide an unambiguous signal that allows for quantitatively determining the fractions of new stemflow in mixtures across the subsurface. After applying the artificial stemflow, soils could be sampled at various depths and distances from the stem base to not only estimate $I_{T}$ but also the shape of the stemflow infiltration plume. Although this soil sampling can be less destructive than the excavations done after dye tests, the soil disturbance still limits the possibility for replication. Challenges include generating artificial stemflow in realistic conditions (i.e., during storms) and at realistic rates (Gonzalez-Ollauri et al., 2020; Guo et al., 2020). Nonetheless, a microcontroller could be used to automatically generate realistic stemflow rates by drawing from a reservoir of deuterated water. Future work could apply these more realistic stemflow rates and 
dynamics directly to tree stems using dyes as well. Using either of these approaches involves the challenge of distinguishing between the effects of how the water is input (i.e., as throughfall or rainfall vs. stemflow) from the effect of the soils (i.e., near-stem soils vs. those less affected by roots).

\section{CONCLUSIONS}

Stemflow can play relevant roles in the coupled hydrology, biogeochemistry, and ecology of vegetated ecosystems; however, its role hinges upon its infiltration area $\left(I_{T}\right)$, and we found little empirical evidence to constrain estimates of that infiltration area. In consideration of how little is known about $I_{T}$, we suggest that little is also known about stemflow's relevance to subsurface processes. These conceptual unknowns do not discount the potential relevance of stemflow to vegetated ecosystems; instead, they justify research opportunities. Future research should seek to address the unknowns that limit our understanding of stemflow's

\section{REFERENCES}

Abdi, E., and Deljouei, A. (2019). Seasonal and spatial variability of root reinforcement in three pioneer species of the Hyrcanian forest. Austrian J. Soil Sci. 136, 175-198.

Allen, S. T., Keim, R. F., Barnard, H. R., McDonnell, J. J., and Renée Brooks, J. (2017). The role of stable isotopes in understanding rainfall interception processes: a review. Wiley Interdiscip. Rev. Water 4:e1187. doi: $10.1002 /$ wat 2.1187

Beven, K. (2018). A century of Denial: preferential and nonequilibrium water flow in soils, 1864-1984. Vadose Zo. J. 17, 1-17. doi: 10.2136/vzj2018.08.0153

Bui, E. N., and Box, J. E. (1992). Stemflow, rain throughfall, and erosion under canopies of corn and sorghum. Soil Sci. Soc. Am. J. 56, 242-247. doi: 10.2136/sssaj1992.03615995005600010037x

Carlyle-Moses, D. E., Iida, S., Germer, S., Llorens, P., Michalzik, B., Nanko, K., et al. (2018). Expressing stemflow commensurate with its ecohydrological importance. Adv. Water Resour. 121, 472-479. doi: 10.1016/j.advwatres.2018.08.015

Cattan, P., Ruy, S. M., Cabidoche, Y.-M., Findeling, A., Desbois, P., and Charlier, J.-B. (2009). Effect on runoff of rainfall redistribution by the impluvium-shaped canopy of banana cultivated on an Andosol with a high infiltration rate. J. Hydrol. 368, 251-261. doi: 10.1016/j.jhydrol.2009.02.020

Charlier, J.-B., Moussa, R., Cattan, P., Cabidoche, Y.-M., and Voltz, M. (2009). Modelling runoff at the plot scale taking into account rainfall partitioning by vegetation: application to stemflow of banana (Musa spp.) plant. Hydrol. Earth Syst. Sci. Discuss. 13, 2151-2168. doi: 10.5194/hess-13-2151-2009

Chinen, T. (2007). An observation of surface runoff and erosion caused by acacia albida stemfolw in dry savanna, in the south-western republic of niger. Geogr. Reports Tokyo Metrop. Univ. 42, 21-30.

Clemente, E. P., Schaefer, C., Novais, R. F., Viana, J. H., and Barros, N. F. (2005). Soil compaction around Eucalyptus grandis roots: a micromorphological study. Soil Res. 43, 139-146. doi: 10.1071/SR04069

de Jonge, L. W., Moldrup, P., and Schjønning, P. (2009). Soil infrastructure, interfaces \& translocation processes in inner space ("Soil-it-is"): towards a road map for the constraints and crossroads of soil architecture and biophysical processes. Hydrol. Earth Syst. Sci. 13, 1485-1502. doi: 10.5194/hess-13-1485-2009

de Ploey, J. (1982). A stemflow equation for grasses and similar vegetation. Catena 9, 139-152. doi: 10.1016/S0341-8162(82)80010-6

Doerr, S. H., and Ritsema, C. J. (2006). Water movement in hydrophobic soils. Encycl. Hydrol. Sci. 14. doi: 10.1002/0470848944.hsa072

Doerr, S. H., Shakesby, R. A., Dekker, L. W., and Ritsema, C. J. (2006). Occurrence, prediction and hydrological effects of water repellency amongst major soil and impacts and interactions across vegetated ecosystems. One of these needs is clearly a better understanding of how and where stemflow infiltrates. Addressing this knowledge gap will not only give funneling ratio metrics physical meaning, but may provide a more empirical signal to direct future investigations of stemflow's relevance and role in ecohydrological processes.

\section{AUTHOR CONTRIBUTIONS}

JV conceived the study. JV and SA reviewed, compiled, and analyzed the past literature. Both authors also equally contributed to the manuscript writing.

\section{ACKNOWLEDGMENTS}

The authors gratefully acknowledge the constructive reviews of Doug P. Aubrey at the Savannah River Ecology Lab and Kevin E. Mueller at Cleveland State University.

land-use types in a humid temperate climate. Eur. J. Soil Sci. 57, 741-754. doi: 10.1111/j.1365-2389.2006.00818.x

Falkengren-Grerup, U. (1989). Effect of stemflow on beech forest soils and vegetation in southern Sweden. J. Appl. Ecol. 341-352. doi: 10.2307/2403671

Fathizadeh, O., Attarod, P., Keim, R. F., Stein, A., Amiri, G. Z., and Darvishsefat, A. A. (2014). Spatial heterogeneity and temporal stability of throughfall under individualQuercus brantiitrees. Hydrol. Process. 28, 1124-1136. doi: 10.1002/hyp.9638

Ferreira, C. S. S., Walsh, R. P. D., Shakesby, R. A., Keizer, J. J., Soares, D., González-Pelayo, O., et al. (2016). Differences in overland flow, hydrophobicity and soil moisture dynamics between Mediterranean woodland types in a peri-urban catchment in Portugal. J. Hydrol. 533, 473-485. doi: 10.1016/j.jhydrol.2015.12.040

Germer, S., Zimmermann, A., Neill, C., Krusche, A. V., and Elsenbeer, H. (2012). Disproportionate single-species contribution to canopy-soil nutrient flux in an Amazonian rainforest. For. Ecol. Manag. 267, 40-49. doi: 10.1016/j.foreco.2011.11.041

Gerrits, A. M. J., and Savenije, H. H. G. (2011). "Forest floor interception," in Forest Hydrology and Biogeochemistry, eds D. F. Levia, D. Carlyle-Moses, and T. Tanaka (Heidelberg: Springer), 445-454. doi: 10.1007/978-94-007-1363-5_22

Gersper, P. L., and Holowaychuk, N. (1971). Some effects of stem flow from forest canopy trees on chemical properties of soils. Ecology 691-702. doi: $10.2307 / 1934160$

Gimbel, K. F., Puhlmann, H., and Weiler, M. (2016). Does drought alter hydrological functions in forest soils? Hydrol. Earth Syst. Sci. 20, 1301-1317. doi: 10.5194/hess-20-1301-2016

Goebel, M., Bachmann, J., Reichstein, M., Janssens, I. A., and Guggenberger, G. (2011). Soil water repellency and its implications for organic matter decomposition-is there a link to extreme climatic events? Glob. Change Biol. 17, 2640-2656. doi: 10.1111/j.1365-2486.2011.0 2414.x

Gómez, J. A., Vanderlinden, K., Giráldez, J. V., and Fereres, E. (2002). Rainfall concentration under olive trees. Agric. Water Manag. 55, 53-70. doi: 10.1016/S0378-3774(01)00181-0

Gonzalez-Ollauri, A., Stokes, A., and Mickovski, S. B. (2020). A novel framework to study the effect of tree architectural traits on stemflow yield and its consequences for soil-water dynamics. J. Hydrol. 582:124448. doi: 10.1016/j.jhydrol.2019.124448

Guo, L., and Lin, H. (2018). Addressing two bottlenecks to advance the understanding of preferential flow in soils. Adv. Agron. 147, 61-117. doi: 10.1016/bs.agron.2017.10.002

Guo, L., Mount, G. J., Hudson, S., Lin, H., and Levia, D. (2020). Pairing geophysical techniques improves understanding of the near-surface critical 
zone: visualization of preferential routing of stemflow along coarse roots. Geoderma 357:113953. doi: 10.1016/j.geoderma.2019.113953

Hall, F. C. (2003). Growth Basal Area Handbook. Rapid City, SD: USDA Forest Service.

Herwitz, S. R. (1986). Infiltration-excess caused by stemflow in a cycloneprone tropical rainforest. Earth Surf. Process. Landforms 11, 401-412. doi: $10.1002 /$ esp. 3290110406

Horton, R. E. (1933). The role of infiltration in the hydrologic cycle. EOS Trans. Am. Geophys. Union 14, 446-460. doi: 10.1029/TR014i001p00446

Iida, S., Kakubari, J., and Tanaka, T. (2005). "Litter marks" indicating infiltration area of stemflow-induced water. Tsukuba Geoenviron. Sci. 1, 27-31.

Iida, S., Shimizu, T., Tamai, K., Kabeya, N., Shimizu, A., Ito, E., et al. (2016), Interrelationships among dry season leaf fall, leaf flush and transpiration: insights from sap flux measurements in a tropical dry deciduous forest. Ecohydrology 9, 472-486. doi: 10.1002/eco.1650

Imamura, N., Levia, D. F., Toriyama, J., Kobayashi, M., and Nanko, K. (2017). Stemflow-induced spatial heterogeneity of radiocesium concentrations and stocks in the soil of a broadleaved deciduous forest. Sci. Total Environ. 599, 1013-1021. doi: 10.1016/j.scitotenv.2017. 05.017

Jelinkova, V., Snehota, M., Pohlmeier, A., van Dusschoten, D., and Cislerova, M. (2011). Effects of entrapped residual air bubbles on tracer transport in heterogeneous soil: magnetic resonance imaging study. Org. Geochem. 42, 991-998. doi: 10.1016/j.orggeochem.2011.03.020

Johnson, M. S., and Lehmann, J. (2006). Double-funneling of trees: stemflow and root-induced preferential flow. Ecoscience 13, 324-333. doi: 10.2980/i1195-6860-13-3-324.1

Keen, B., Cox, J., Morris, S., and Dalby, T. (2010). "Stemflow runoff contributes to soil erosion at the base of macadamia trees," in 19th World Congress of Soil Science, Soil Solutions for a Changing World (Brisbane), 240-243.

Levia, D. F., and Germer, S. (2015). A review of stemflow generation dynamics and stemflow-environment interactions in forests and shrublands. Rev. Geophys. 53, 673-714. doi: 10.1002/2015RG000479

Linden, D. R., and Dixon, R. M. (1976). Soil air pressure effects on route and rate of infiltration. Soil Sci. Soc. Am. J. 40, 963-965. doi: $10.2136 /$ sssaj1976.03615995004000060042x

McKee, A. J., and Carlyle-Moses, D. E. (2017). Modelling stemflow production by juvenile lodgepole pine (Pinus contorta var. latifolia) trees. J. For. Res. 28, 565-576. doi: 10.1007/s11676-016-0336-9

Metzger, J. C., Schumacher, J., Lange, M., and Hildebrandt, A. (2019). Neighbourhood and stand structure affect stemflow generation in a heterogeneous deciduous temperate forest. Hydrol. Earth Syst. Sci. doi: 10.5194/hess-2019-336

Moresi, F. V., Maesano, M., Matteucci, G., Romagnoli, M., Sidle, R. C., and Scarascia Mugnozza, G. (2019). Root biomechanical traits in a montane mediterranean forest watershed: variations with species diversity and soil depth. Forests 10:341. doi: 10.3390/f10040341

Pressland, A. J. (1973). Rainfall partitioning by an arid woodland (Acacia aneura F. Muell.) in south-western Queensland. Aust. J. Bot. 21, 235-245. doi: 10.1071/BT9730235
Pressland, A. J. (1976). Soil moisture redistribution as affected by throughfall and stemflow in an arid zone shrub community. Aust. J. Bot. 24, 641-649. doi: 10.1071/BT9760641

Rashid, N. S. A., and Askari, M. (2014). "Litter marks" around oil palm tree base indicating infiltration area of stemflow-induced water. Natl. Semin. Civ. Eng. Res. Johor Bahru.

Riegler, W. (1881). Beobachtungen über die Abfuhr meteorischen Wassers entlang den Hochstämmen. Mitteil. Forstl. Bundes Versuchsanstalt Wien 2, 234-246.

Ryan, P. J., and McGarity, J. W. (1983). The nature and spatial variability of soil properties adjacent to large forest eucalypts. Soil Sci. Soc. Am. J. 47, 286-293. doi: 10.2136/sssaj1983.03615995004700020023x

Schwärzel, K., Ebermann, S., and Schalling, N. (2012). Evidence of doublefunneling effect of beech trees by visualization of flow pathways using dye tracer. J. Hydrol. 470-471, 184-192. doi: 10.1016/j.jhydrol.2012.08.048

Snelgrove, J. R., Buttle, J. M., and Tetzlaff, D. (2020). Importance of rainfall partitioning in a northern mixed forest canopy for soil water isotopic signatures in ecohydrological studies. Hydrol. Process. 34, 284-302. doi: 10.1002/hyp.13584

Spencer, S. A., and van Meerveld, H. J. (2016). Double funnelling in a mature coastal British Columbia forest: spatial patterns of stemflow after infiltration. Hydrol. Process. 30, 4185-4201. doi: 10.1002/hyp.10936

Tanaka, T., Taniguchi, M., and Tsujimura, M. (1996). Significance of stemflow in groundwater recharge. 2: a cylindrical infiltration model for evaluating the stemflow contribution to groundwater recharge. Hydrol. Process. 10, 81-88. doi: 10.1002/(SICI) 1099-1085(199601)10:1<81::AID-HYP302>3.0.CO;2-M

Tanaka, T., Tsujimura, M., and Taniguchi, M. (1991). Infiltration area of stemflowinduced water. Annu. Rep. Inst. Geosci. Univ. Tsukuba 30-32.

Van Stan, J. T., and Gordon, D. A. (2018). Mini-review: stemflow as a resource limitation to near-stem soils. Front. Plant Sci. 9:248. doi: 10.3389 /fpls.2018.00248

Van Stan, J. T., Lewis, E. S., Hildebrandt, A., Rebmann, C., and Friesen, J. (2016). Impact of interacting bark structure and rainfall conditions on stemflow variability in a temperate beech-oak forest, central Germany. Hydrol. Sci. J. 61, 2071-2083. doi: 10.1080/02626667.2015.1083104

Voigt, G. K. (1960). Alteration of the composition of rainwater by trees. Am. Midl. Nat. 6, 321-326. doi: 10.2307/2422795

Zimmermann, A., and Zimmermann, B. (2014). Requirements for throughfall monitoring: the roles of temporal scale and canopy complexity. Agric. For. Meteorol. 189, 125-139. doi: 10.1016/j.agrformet.2014.01.014

Conflict of Interest: The authors declare that the research was conducted in the absence of any commercial or financial relationships that could be construed as a potential conflict of interest.

Copyright (๑) 2020 Van Stan and Allen. This is an open-access article distributed under the terms of the Creative Commons Attribution License (CC BY). The use, distribution or reproduction in other forums is permitted, provided the original author(s) and the copyright owner(s) are credited and that the original publication in this journal is cited, in accordance with accepted academic practice. No use, distribution or reproduction is permitted which does not comply with these terms. 